\title{
Measurement properties of the questionnaire "Mosaic of opinions on induced abortion": a multicenter study in seven Brazilian hospitals
}

\author{
Denis Barbosa Cacique \\ Renato Passini Junior ${ }^{1}$ \\ Maria José Martins Duarte Osis² \\ Henrique Ceretta Oliveira ${ }^{3}$ \\ Kátia Melissa Padilha ${ }^{4}$ \\ Ricardo Porto Tedesco ${ }^{5}$ \\ Janete Vettorazzi ${ }^{6}$ \\ Denis José Nascimento ${ }^{7}$ \\ Pedro Ribeiro Coutinho ${ }^{8}$ \\ Isabela C. Coutinho \\ Francisco Edson de Lucena Feitosa ${ }^{10}$
}

1. Department of Obstetrics and Gynecology, University of Campinas School of Medicine, Campinas (SP), Brasil 2. Medical School of Jundiaí, Jundiaí (SP), Brasil 3. University of Campinas Nursing School, Campinas (SP), Brasil 4. Woman's Hospital Prof. Dr. J. A. Pinotti-CAISM. Campinas (SP), Brasil 5. Medical School of Jundiaí, Jundiaí (SP), Brasil 6. Hospital of Clinics of Porto Alegre (HCPA) - UFRGS, Porto Alegre (RS), Brasil

7. Hospital of Clinics of Federal University of Paraná, Curitiba (PR), Brasil 8. Sumaré State Hospital, Sumaré (SP), Brasil 9. Woman's Hospital of Recife, Recife (PE), Brasil 10. Maternity School Assis Chateaubriand, Fortaleza (CE), Brasil

http://dx.doi.org/10.1590/1806-9282.64.12.1091

\section{SUMMARY}

In Brasil, abortion is legal in cases of rape, when there is a risk of maternal death, and in cases of fetal anencephaly. However, the literature reports that some doctors refuse to care for women with such demands or come to perform it in a discriminatory manner.

OBJECTIVE: Pretest, test and evaluate the measurement properties of the "Mosaic of Opinions on Induced Abortion," a questionnaire developed to investigate the perspectives of Brazilian healthcare professionals about the morality of abortion.

METHODS: Firstly, the questionnaire was pretested in an intentional sample of specialists. Secondly, it was tested in a randomized sample of 32 healthcare professionals. Finally, we conducted a multi-center study in seven university hospitals to evaluate the measurement properties of the questionnaire.

RESULTS: Combined samples of the three phases totalized 430 individuals. In pretest and test, all the evaluated aspects obtained satisfactory results. In the multicenter phase, confirmatory factorial analysis led to an important reduction of the questionnaire, which also obtained good indicators of reliability, beyond the validation of construct and criteria.

CONCLUSION: Questionnaire has been validated and is suitable for use in other surveys in Brasil.

KEYWORDS: Validation Studies. Abortion, Induced. Attitude of Health Personnel. Ethics. Surveys and Questionnaires.

DATE OF SUBMISSION: 25-Mar-2018

DATE OF ACCEPTANCE: 07-May-2018

CORRESPONDING AUTHOR: Denis Cacique

Rua Alexander Fleming, 101, Cidade Universitária Zeferino Vaz - Campinas, SP - CEP 13083-881

Diretoria Associada. Caism

E-mail: denisbarbosa.c@gmail.com 


\section{HIGHLIGHTS}

- MOSAI evaluates the opinions of healthcare professionals on induced abortion;

- MOSAI has been validated and is suitable for use in other surveys in Brazil;

- After an evaluation of measurement properties, we reduced the questionnaire from 42 to 32 items;

- The questionnaire has content, construct and criterion validity;

- All constructs obtained high composite reliability coefficients (minimum of 0.770 ).

\section{INTRODUCTION}

Providing care to women in situations of induced abortion constitutes one of the most challenging ethical problems for healthcare professionals, especially for gynecological and obstetric doctors. This challenge is reflected in the fact that, in Brazil, although permitted by the Penal Code of 1940, access to legal abortion is still problematic, mainly when the pregnancy results from rape. In some reference services, prevails a regime of constant suspicion about the veracity of the woman's narrative on rape: her story is not sufficient for getting access to the procedure, being necessary to prove herself as a victim of aggression and to present subjective traits that characterize her as such. ${ }^{1}$ Obstruction to legal abortion also occurs through the obligation to present a series of documents not required by law, such as police reports, forensic reports, and court orders. ${ }^{2}$ Frequently, the patient receives no guidance on the procedures performed or on the care that will be needed after the procedure, such as subsequent contraception. ${ }^{3} \mathrm{~A}$ survey of 19 women who had aborted in private clinics found that they were exposed to a condition of total vulnerability and human rights violations, such as the submission to painful medical procedures without anesthesia, like curettage and vacuum suction. ${ }^{4}$

Although abortion techniques are safe, effective and inexpensive and have been well known for many decades, health care professionals (HCP) lack adequate knowledge of laws and norms around the theme, such as the misconception about the need to denounce the woman when there signs of illegal interruption., ${ }^{2,5}$ Alongside the inefficient knowledge of the legislation on the subject, the provision of abortion care constitutes a tremendous ethical challenge to HCP. Even in cases where it is permitted by law, "the concept that it is a crime carries a stigma that is worse than that associated with other acts qualified by law as crimes. ${ }^{16}$ In this context, the existence of a validated questionnaire to investigate the opinions of HCP could contribute to the production of systematized information on the subject, which could guide the development of new public health policies to combat barriers to access legal and safe abortion in Brazil.

We provide the "Mosaic of Opinions on Induced Abortion" (abbreviated in Portuguese by the acronym "MOSAI")'; the one presented was created as a candidate to meet this demand. ${ }^{7}$ Although other studies have investigated the moral perspectives of Brazilian HCP on abortion, their methods were exclusively qualitative, which means that their samples had few professionals. ${ }^{5}$ On the other hand, MOSAI is predominantly quantitative and can be applied on large samples. Similar scales of evaluation of the morality of abortion have been elaborated in some countries with restrictive laws on its practice, ${ }^{8,9}$ but they are intended to be used by people in general (not only by HCP) and are not validated to the specificities of the Brazilian context.

Thereby, the objectives of this study were to pretest, test and evaluate the measurement properties of the questionnaire MOSAI.

\section{METHODS}

Study design, sampling, and questionnaire

We performed a methodological study comprised of three interlinked phases. In all of them, we applied the questionnaire online through the Lime Survey website. All the subjects received the link to MOSAI via e-mail, after they were personally invited by the researchers and consented with being included in it.

The present study uses the terminology established by the COSMIN initiative (COnsensus-based Standards for the selection of health Measurement INstruments), according to which the term "properties of the measure" refers to a set of quality indicators of an instrument, including validity (content, criteria and construct), reliability and responsiveness. ${ }^{10}$

In this study, we used the brief version of the MOSAI questionnaire, which contains three vignettes about women considering interrupting the pregnancy. Those vignettes are based on the situations in which abortion is allowed in Brazil: necessary abortion (when there is a risk of death to the mother), humanitarian abortion and anencephalic fetus. After these 
vignettes, MOSAI presents some short affirmative phrases (from now on referred to as "items") based on patterns of views on the morality of abortion, which must be classified employing a concordance scale. The questionnaire's complete version has six vignettes and, beyond the demands mentioned above, includes cases of social abortion, contraceptive failure, and fetus with trisomy $21 .^{7}$

Concerning the factorial structure of the questionnaire, MOSAI was created and had its content validated with 14 constructs. ${ }^{7}$ However, in the present study, since we used its brief version, we reassembled these 14 constructs into eight new ones. The process of regrouping consisted in the separation of items characterized by a liberal or a conservative moral alignment regarding the possibility of someone performing an abortion. This process resulted in the two large groups of items, the Liberal and the Conservative. After that, we formed eight subgroups of items, four liberals and four conservatives, as defined below:

1. Psychological Aftereffects of Abortion (PAA): Appeal to the possible psychological aftereffects of abortion, or to the familiar approval or disapproval of having an abortion. Although the relationship between post-traumatic stress and abortion is questioned in some studies, ${ }^{11}$ in Brazil, a study found that women in situations of abortion had a higher prevalence of depression. ${ }^{12}$

2. Conservative Emotional Appeal (CEA): Use of shocking expressions and images (like "murder" and "cruelty") or by the equalization of the fetus and the embryo to a born child.

3. Sacredness of Life (SOL): Argument that abortion is always morally reprehensible, either because human life is sacred (even in the early stages), or because the fetus is a potential person.

4. Conservative Deontology (CDE): Argument that parents have a moral duty to protect the fetus or that abortion is wrong if the woman lies about having been raped (to have access to legal abortion), or if she supposedly had any behavior that could be considered risky for rape (by people who agree with this reasoning).

5. Women's Reproductive Autonomy (WRA): Argument that women should have the right to decide whether to abort or not, according to her values and interests. The concept of autonomy occupies a central position in this construct.

6. Liberal Emotional Appeal (LEA): Invocation of shocking expressions and images in favor of the right to induce an abortion, like "torture" and "assassination" of the mother.

7. Sexual and Reproductive Rights (SRR): Argument that the denial of abortion care violates women's fundamental human rights and promotes a public health problem.

8. Fetal Personhood Problematization (FPP): Argument that the human unborn does not have moral status (at least in some circumstances) or that its life is not sacred.

\section{Testing Phases}

MOSAI was pre-tested in an intentional sample of researchers in health sciences and humanities from the State University of Campinas (UNICAMP). Using some auxiliary questions presented at the end of MOSAI, we evaluated: 1) The presence of wording errors; 2) The questionnaire functionality; 3) Its ease of using; 4) Its content comprehensibility; and 5) The satisfaction with the necessary time to answer it. Subjects also could freely write about the evaluated aspects through an open question. The saturation of the qualitative data defined the sample size.

The test phase was developed in the "Woman's Hospital Prof. Dr. J. A. Pinotti-CAISM," which belongs to UNICAMP. We employed a version of MOSAI containing changes identified as necessary during the pre-test. Even so, the objective of this phase was to reevaluate the same aspects evaluated before. The sample was randomly selected (using the software SPSS 20) from the list of physicians, nurses, psychologists, social workers and pharmacists of the hospital. The sample size was defined in 32 subjects, following the recommendation for questionnaire tests.

\section{The Multicenter Phase}

After the testing phases, we conducted a multi-center study aiming to evaluate the measurement properties of MOSAI. This stage of the research was conducted in seven hospitals selected from the Brazilian Network of Reproductive and Perinatal Health, namely: 1. Woman's Hospital of Recife; 2. Maternity School Assis Chateaubriand; 3. Hospital of Clinics of Porto Alegre; 4. Hospital of Clinics of Federal University of Paraná; 5. University Hospital of the Jundiaí Medical School; 6. Sumaré State Hospital-UNICAMP; and 7. Woman's Hospital Prof. Dr. J. A. Pinotti-CAISM). The sample was constituted of physicians, nurses, psychologists, social workers, 
and pharmacists, selected by a convenience sampling method. We adopted the sample size calculation for factor analysis proposed by Hair et al., which suggest a ratio of 5 respondents per item of the scale and a minimum of 100 items in total. ${ }^{13}$ To ensure a better quality of the data collected, we removed all the questionnaires answered incompletely or which had at least one item answered with the "do not know" option.

Validation of the measurement properties was performed employing a Confirmatory Factorial Analysis (CFA) with the software Smart PLS 2.0. We hypothesized that the questionnaire had a second order factorial structure, that is, a structure organized through two layers of latent constructs. ${ }^{13}$ The composition of these layers followed the so-called "a priori criterion," used when the number of factors is already known. ${ }^{13}$ The first layer has two great constructs: Liberal and Conservative orientations. The second layer contains the eight patterns described previously.

Analysis of the factorial model comprised two steps: analysis of the convergent and discriminant validity of the proposed model. In the case of convergent analysis, initially, we obtained the results from the mean extracted variance (AVE) for each of the model factors. AVE values higher than 0.5 indicate considerate satisfactory. ${ }^{13}$ Subsequently, we evaluated the values of factorial loads between the items and their respective factors, assuming that items with results lower than 0.5 were candidates to leave the factorial model. ${ }^{13}$ Discriminant validity was first evaluated by the Fornell-Larcker criterion. ${ }^{14}$ This method compares the square root of the AVEs with the correlation values between the factors. The model has discriminant validity if the square roots of the AVEs are higher than the correlations between the factors. Discriminant validity was also evaluated through a cross-loadings analysis. It was observed whether the factorial load of a given item was higher in its factor than in the other factors. To obtain the internal consistency of the questionnaire, we calculated the composite reliability, considering that values above 0.7 would be satisfactory. ${ }^{13}$ Finally, validation by known groups was performed by comparing MOSAI scores between religious and non-religious subjects, using the non-parametric test of Mann-Whitney. ${ }^{15}$ We hypothesized that, compared to non-religious subjects, religious subjects would have higher scores in the conservatives constructs. In all analyzes, the level of statistical significance was set at $5 \%{ }^{15}$

\section{Ethical Aspects}

This project was reviewed and approved by the Research Ethics Committee of the State University of Campinas (UNICAMP), as well as by the Institutional Review Board of each site enrolled in the multi-center phase. Before enrolment, an individual Informed Consent form was electronically signed by each subject after understanding and accepting the study conditions. To assure the confidentiality, we excluded from the data analysis the subject's names or any other variable that could identify them.

\section{RESULTS}

Testing

The questionnaire was pre-tested in a sample of 10 subjects, six women and four men. The mean age was 39.0 years (max. 51.0 and min. 29.0). Subjects had a degree in Philosophy (1), Letters (1), Statistics (4), Social Sciences (2), Pharmacy (1) and Biology (1). No participant reported technical difficulties with the questionnaire, but a spelling error was identified and corrected. One subject reported that it was necessary to restart the questionnaire, due to an error in his browser. Both the "ease of use" and the "writing comprehensibility" were classified as "easy" or "very easy" by most of the subjects. Most the sample classified the time spent as moderately satisfactory.

After the pre-test, the corrected version of MOSAI was tested in a sample of 32 HCP. They were 25 women and 7 men, distributed among the following professional categories: Physicians (12), Nurses (11), Social Workers (3), Pharmacists (3) and Psychologists (3). The mean age was 39.7 years (max. 56.0 and min. 23.0). Catholicism was the most common religion among the participants (17), followed by Spiritism (7) and Protestantism (3). Five subjects were atheists or not religious (5). Almost all participants positively evaluated the grammatical, spelling, online functionality, ease of use and comprehensibility of MOSAI. The time required to answer it received the lowest classification among all the evaluated aspects, but none classified it as "bad" or "very bad."

The detailing of the pre-test and test results are not presented in this article. However, such data may be made available by the authors upon request.

\section{Measurement properties validation}

The initial sample for statistical validation consisted of 388 subjects: 133 were excluded because 
they answered at least one item with the "do not know" option and 133 were excluded because they did not respond to at least one questionnaire item. Once the exclusion criterion was applied, the final sample consisted of 122 subjects. When comparing the excluded subjects with those maintained in the analysis, it was verified that there was no statistically significant difference between the characteristics of age, profession, and religiosity. However, these samples were different for gender $(p=0.0332)$, with a higher proportion of women in the excluded group (78.63\% vs. $66.67 \%)$; and marital status ( $p=$ 0.0438), with a higher percentage of people in stable union in the group included in the analysis $(71.9 \%$ vs. 59.85\%). As shown in Table 1, most of the subjects kept in the study were women (66.7\%), the mean age was 38.0 years (max. 69.0 min. 21.0), the most common religion was Catholicism (57.1\%), and the main marital status was married (57.9\%). Almost $80.0 \%$ of the sample was post-graduate, and $78.1 \%$ were physicians, most of them specialized in gynecology and

TABLE 1: DESCRIPTION OF THE SAMPLE OF HEALTH PROFESSIONALS WHO PARTICIPATED IN THE EVALUATION OF THE MOSAI MEASUREMENT PROPERTIES

\begin{tabular}{|c|c|c|}
\hline Information & $\mathrm{N}$ & $\%$ \\
\hline \multicolumn{3}{|l|}{ Gender } \\
\hline Female & 80 & 66.67 \\
\hline Male & 40 & 33.33 \\
\hline Age (Mean/SD) & $38( \pm 11)$ & - \\
\hline \multicolumn{3}{|l|}{ Religion } \\
\hline Religious $^{1}$ & 97 & 81.51 \\
\hline Not Religious & 22 & 18.49 \\
\hline \multicolumn{3}{|l|}{ Marital Status } \\
\hline Married or Cohabitating & 86 & 71.07 \\
\hline Single or Divorced & 34 & 28.10 \\
\hline Widower & 1 & 0.83 \\
\hline \multicolumn{3}{|l|}{ Schooling } \\
\hline Postgraduate & 85 & 77.27 \\
\hline Graduate & 21 & 19.09 \\
\hline High School + Technical & 4 & 3.64 \\
\hline \multicolumn{3}{|l|}{ Occupation } \\
\hline Physician (Gyn-Obst) & 64 & 52.03 \\
\hline Nurse & 20 & 16.26 \\
\hline Doctor (Other Specialty) & 16 & 13.01 \\
\hline Resident Doctor $^{2}$ & 16 & 13.01 \\
\hline Pharmaceutical & 4 & 3.25 \\
\hline Psychologist & 2 & 1.63 \\
\hline Social Worker & 1 & 0.81 \\
\hline
\end{tabular}

obstetrics. Approximately half of the sample worked in general hospitals and half of them in hospitals specialized in women's health.

The first step of CFA was the exclusion of item Q11 (Abortion should be based on a reliable diagnosis of anencephaly, that is, the certainty that the unborn child will never have a future), which had a negative load in the proposed construct. To obtain the convergent validity, we excluded the items Q20 (It is psychologically difficult for a health care professional to have to terminate the pregnancy of a healthy fetus) and Q08 (Women who interrupt pregnancy in cases of anencephaly may be under pressure from their partners), whose low factorial loads caused their respective constructs to have AVEs lower than 0.50. After that, all constructs obtained AVEs greater than 0.50, as shown in Table 2.

To obtain the discriminant validity, we applied the Fornell-Larcker criteria and removed the items Q5 (If the Federal Supreme Court had not authorized abortion in cases of anencephaly, women like Jussara would recourse to illegal abortion), Q09 (The laws that regulate life in society cannot be based on religious beliefs of specific groups), Q16 (The high mortality rates for pregnant women with this disease justify abortion to protect the mother's life), Q29 (The right to abortion in rape cases is an important way to combat maternal mortality), Q35 (Marina must keep in mind that life is sacred regardless of how it was generated), Q36 (Legal abortion in cases of rape frees the victims of the horror of carrying a life created in an act of terrible violence) and Q38 (Discontinuation of a healthy fetus's pregnancy can be considered a form of violence against the weakest).

TABLE 2: MOSAI'S EXTRACTED AVERAGE VARIANCE AND COMPOSITE RELIABILITY

\begin{tabular}{l|l|l} 
Constructs & AVE & $\begin{array}{l}\text { Composite } \\
\text { Reliability }\end{array}$ \\
\hline Conservative Constructs & & \\
\hline $\begin{array}{c}\text { Psychological Aftereffects of Abortion } \\
\text { (PAA) }\end{array}$ & 0.612 & 0.824 \\
\hline Conservative Emotional Appeal (CEA) & 0.586 & 0.808 \\
\hline Sacredness of Life (SOL) & 0.582 & 0.892 \\
\hline Conservative Deontology (CDE) & 0.522 & 0.813 \\
\hline Liberal Constructs & & \\
\hline $\begin{array}{c}\text { Women's Reproductive Autonomy } \\
\text { (WRA) }\end{array}$ & 0.622 & 0.891 \\
\hline Liberal Emotional Appeal (LEA) & 0.627 & 0.770 \\
\hline Sexual and Reproductive Rights (SRR) & 0.634 & 0.912 \\
\hline Fetal Personhood Problematization (FPP) & 0.531 & 0.771 \\
\hline
\end{tabular}


Once these adjustments were made, the final model was composed of 32 items, whose constructs and respective factor loads are shown in Table 3. In the next step, we calculated the composite reliability. As shown in Table 2, all the constructs obtained scores higher than 0.70 . To receive the validation of criteria, we observed that religious group presented higher scores in most of the constructs with conservative orientation arguments, including CEA, SOL, and CDE. In contrast, the non-religious group showed higher scores in two liberal-oriented domains, including WRA and FPP (p-value <0.05). Detailed results of validation by known groups are not presented but may be made available by the authors upon request. Besides, the database analyzed was made available to " $\mathrm{R}$ da A M B" at the time of the article submission. This database may also be made available to readers upon request.

\section{DISCUSSION}

Testing

In testing stages, all the evaluated aspects obtained satisfactory results. Although the time spent received the lowest rating among all aspects, no subject classified it as "bad" or "very bad." This is a significant result since the quality of filling in questionnaires tends to be inversely proportional to the time

TABLE 3: MOSAI'S FINAL FACTORS LOADING MATRIX.

\begin{tabular}{|c|c|c|c|c|c|c|c|c|}
\hline \multirow[b]{2}{*}{$\begin{array}{l}\frac{\varepsilon}{d} \\
\pm\end{array}$} & \multicolumn{8}{|c|}{ Constructs } \\
\hline & $\begin{array}{l}\text { Psychological } \\
\text { Aftereffects } \\
\text { of Abortion } \\
\text { (PAA) }\end{array}$ & $\begin{array}{l}\text { Conservative } \\
\text { Emotional } \\
\text { Appeal (CEA) }\end{array}$ & $\begin{array}{l}\text { Sacredness } \\
\text { of Life } \\
\text { (SOL) }\end{array}$ & $\begin{array}{l}\text { Conservative } \\
\text { Deontology } \\
\text { (CDE) }\end{array}$ & $\begin{array}{l}\text { Women's } \\
\text { Reproductive } \\
\text { Autonomy } \\
\text { (WRA) }\end{array}$ & $\begin{array}{l}\text { Liberal } \\
\text { Emotional } \\
\text { Appeal } \\
\text { (LEA) }\end{array}$ & $\begin{array}{l}\text { Sexual and } \\
\text { Reproductive } \\
\text { Rights (SRR) }\end{array}$ & $\begin{array}{l}\text { Fetal Personhood } \\
\text { Problematization } \\
\text { (FPP) }\end{array}$ \\
\hline Q30 & 0.844 & 0.477 & 0.503 & 0.475 & -0.423 & -0.233 & -0.349 & -0.346 \\
\hline Q14 & 0.820 & 0.333 & 0.492 & 0.382 & -0.393 & -0.251 & -0.341 & -0.309 \\
\hline Q23 & 0.672 & 0.317 & 0.332 & 0.261 & -0.214 & -0.141 & -0.154 & -0.128 \\
\hline Q04 & 0.439 & 0.809 & 0.584 & 0.472 & -0.530 & -0.466 & -0.481 & -0.356 \\
\hline Q32 & 0.388 & 0.803 & 0.590 & 0.449 & -0.553 & -0.231 & -0.490 & -0.373 \\
\hline Q17 & 0.281 & 0.678 & 0.529 & 0.457 & -0.397 & -0.319 & -0.443 & -0.190 \\
\hline Q19 & 0.443 & 0.594 & 0.827 & 0.502 & -0.567 & -0.379 & -0.581 & -0.373 \\
\hline Q22 & 0.403 & 0.544 & 0.826 & 0.531 & -0.618 & -0.486 & -0.686 & -0.414 \\
\hline Q06 & 0.417 & 0.568 & 0.784 & 0.495 & -0.713 & -0.433 & -0.629 & -0.501 \\
\hline Q31 & 0.515 & 0.663 & 0.778 & 0.621 & -0.633 & -0.346 & -0.587 & -0.474 \\
\hline Q02 & 0.358 & 0.512 & 0.722 & 0.479 & -0.604 & -0.411 & -0.541 & -0.412 \\
\hline Q27 & 0.491 & 0.500 & 0.618 & 0.528 & -0.318 & -0.306 & -0.340 & -0.289 \\
\hline Q40 & 0.284 & 0.386 & 0.450 & 0.769 & -0.308 & -0.281 & -0.310 & -0.355 \\
\hline Q41 & 0.410 & 0.470 & 0.483 & 0.737 & -0.427 & -0.217 & -0.333 & -0.358 \\
\hline Q01 & 0.420 & 0.589 & 0.622 & 0.736 & -0.624 & -0.390 & -0.478 & -0.395 \\
\hline Q28 & 0.265 & 0.206 & 0.402 & 0.641 & -0.211 & -0.211 & -0.123 & -0.190 \\
\hline Q39 & -0.419 & -0.614 & -0.630 & -0.495 & 0.830 & 0.460 & 0.649 & 0.494 \\
\hline Q34 & -0.402 & -0.462 & -0.538 & -0.450 & 0.821 & 0.442 & 0.635 & 0.551 \\
\hline Q13 & -0.393 & -0.603 & -0.680 & -0.535 & 0.795 & 0.520 & 0.612 & 0.489 \\
\hline Q10 & -0.316 & -0.434 & -0.619 & -0.418 & 0.774 & 0.413 & 0.550 & 0.439 \\
\hline Q25 & -0.243 & -0.434 & -0.533 & -0.357 & 0.718 & 0.483 & 0.606 & 0.381 \\
\hline Q07 & -0.252 & -0.404 & -0.453 & -0.408 & 0.517 & 0.855 & 0.547 & 0.438 \\
\hline Q15 & -0.171 & -0.288 & -0.358 & -0.185 & 0.405 & 0.723 & 0.378 & 0.316 \\
\hline Q12 & -0.306 & -0.548 & -0.715 & -0.434 & 0.729 & 0.513 & 0.851 & 0.549 \\
\hline Q26 & -0.343 & -0.518 & -0.645 & -0.340 & 0.675 & 0.561 & 0.851 & 0.455 \\
\hline Q33 & -0.322 & -0.537 & -0.624 & -0.415 & 0.625 & 0.414 & 0.840 & 0.506 \\
\hline Q42 & -0.385 & -0.517 & -0.544 & -0.353 & 0.634 & 0.434 & 0.794 & 0.572 \\
\hline Q21 & -0.138 & -0.358 & -0.455 & -0.301 & 0.505 & 0.492 & 0.758 & 0.337 \\
\hline Q18 & -0.268 & -0.444 & -0.532 & -0.322 & 0.500 & 0.424 & 0.668 & 0.306 \\
\hline Q37 & -0.323 & -0.383 & -0.434 & -0.380 & 0.473 & 0.327 & 0.428 & 0.768 \\
\hline Q03 & -0.319 & -0.277 & -0.421 & -0.348 & 0.472 & 0.474 & 0.471 & 0.759 \\
\hline Q24 & -0.085 & -0.218 & -0.316 & -0.276 & 0.352 & 0.225 & 0.357 & 0.653 \\
\hline
\end{tabular}


required to answer it. ${ }^{16}$ Very long questionnaires may tire the subjects and compromise the uniformity of responses.

Most of the respondents rated the use of the questionnaire over the internet as "easy" or "very easy." Digital methods for data collection have some advantages over traditional methods: they broaden the sample range, reduce costs and eliminate the environmental damages associated with printing papers. However, the use of conventional questionnaires is still the preferred method for certain groups of people. One study found that the response rate for digital questionnaires was lower than for questionnaires printed in a group of physicians. ${ }^{17}$ Nevertheless, it is argued that such preferences may be related to characteristics of the sample, especially schooling and age of the participants, as such that the collection method (online or paper) may be indifferent to the quality of the data obtained. ${ }^{18}$

\section{Measurement properties validation}

CFA led to an essential reduction of the questionnaire and an increase in the indicators of composite reliability, convergent validity, and divergent validity. Shorter instruments have significant advantages both in clinical practice and research: they do not require excessive interviewer time, reduce the burden of response and are beneficial when administered as part of a multipurpose battery of different questionnaires or when repeat assessments are required. ${ }^{19}$ Shorter versions of scales achieve a higher acceptability in the population, including better response rates and lower rates of missing data. ${ }^{20}$ Although widely recognized as beneficial, it is recommended that researchers carefully examine the effects of each item removal on the construct content validity. ${ }^{21}$ In this study, we removed 10 items from the questionnaire applied. Item Q11 was the only exclusion due to a negative factorial load. Originally bound to construct SOL, this phrase was conceived as a conservative statement regarding the right to abortion. However, the statistical analysis evidenced that its formulation had been ambiguous, leading to a liberal interpretation. The low (but positive) factor loads of items Q8 and Q20 resulted from a different problem. Both do not appear to have been formulated ambiguously, but they pointed to narrative elements that were not addressed by any other part of the questionnaire: the husband of the pregnant woman and the healthcare professional.
Items Q5, Q09, Q16, Q29, Q35, Q36, and Q38 were excluded because they presented high correlation with domains other than those to which they belonged, compromising the discriminating validity. Items Q5 and Q29 called for an implicit idea: that women necessarily undergo an unsafe abortion when the procedure is prohibited by law. This notion is erroneous. For instance, a recent study noted that some women choose to maintain their pregnancies even in cases of sexual abuse, a condition for which abortion is permitted under Brazilian law. ${ }^{22}$ Item Q16 formulation was problematic too. It suggested that Eisenmenger syndrome is highly incidental, but we meant to say that, in pregnancy, it is associated with high mortality rates, from 30 to $50 \%{ }^{23}$ However, these estimates may be outdated. Although pregnancy is still discouraged in women with this syndrome, nowadays it is known that the use of sildenafil as monotherapy may allow stabilization of maternal condition and improve clinical outcomes for both mother and baby. ${ }^{24}$

We were not surprised by the need to exclude item Q38. Inspired by a dissident line of traditional feminist thinking, this item assumes that "a woman involuntary pregnant has a moral obligation to the now-existing dependent fetus whether she explicitly consented to it or not". ${ }^{25}$ Self-called "pro-life feminism", this atypical perspective on the ethics of abortion was probably perceived by the sample as strange, modifying the expected pattern of response.

On the other hand, it was quite surprising that the correlation of item Q09 was greater outside than inside its construct. This item deals explicitly with the theme of secularity, which is one of the central ideas of the SRR construct. According to this argument, "religion should be a matter of private ethics, and public policies should not be based on religious mystics concerning welfare". ${ }^{26}$ It should be noted that more than $80 \%$ of our sample considered themselves as religious, $68 \%$ of them with a Judeo-Christian orientation. That is, this important sample trait may have influenced the unexpected response pattern.

Despite the predominance of religious subjects, item Q35 also had to be excluded according to the Fornell-Larcker criterion. This item argues in favor of the sacredness of life, the idea that any form of human life has an intrinsic and sacred value. However, it should be noted that, even for a predominantly religious group, the unrestricted prohibition of abortion rights can be rejected, especially in cases such 
as sexual abuse. On the other hand, it does not mean that the same group would agree with a theatrical appeal in favor of the right to abortion, like the content of item Q36.

The relationship between religiosity and abortion morality was used to obtain the validation by known groups. According to studies conducted in Brazil and other Latin American countries, ${ }^{9,27-29}$ religious groups (especially Catholics and Protestants) show strong opposition to the right to abortion, a result also observed in the present study, which endorses the criterion validity of MOSAI. In addition to the opposing to liberal arguments, we found that the religious group showed close acceptance of conservative arguments, including those characterized by an emotional appeal.

A final point to be discussed in this paper refers to a possible role to be played by MOSAI in the context of Brazilian public health. In one of its most recurrent definitions, elaborated by the Institute of Medicine (IoM), public health is understood as "what we as a society do collectively to assure the conditions in which people can be healthy", including, as a core function, the production, and monitoring of information related to the health of the population, aiming at identifying problems and defining priorities. ${ }^{30}$ In this sense, it can be inferred that MOSAI could become a relevant instrument in the production and monitoring of information regarding the barriers to access to legal and safe abortion in Brazil. For example, new studies developed with this questionnaire may correlate the perspectives of HCP with the practice of conscientious objection. In doing so, MOSAI may contribute to another core function of public health, which is the development of public policies, "in collaboration with community and government leaders, to solve identified local and national health problems and priorities." 30

\section{Limitations}

The high number of missing items during the measurement properties validation can be considered the main limitation of this study. Only twothirds of all administered questionnaires were fully answered, of which half had to be excluded because they had at least one item answered with the "do not know" option. Women had a higher proportion in the group of subjects excluded from the analysis.

Meanwhile, people in a stable relationship had a higher proportion among the subjects who duly answered the questionnaire. Although the data collected in this study do not allow us to draw further conclusions on the issue, it seems safe to infer that men and women respond to moral dilemmas related to induced abortion differently, since men and women experience this phenomenon very differently. Men do not get pregnant, do not abort. For them, answering the types of dilemmas proposed by MOSAI may be done in a cooler, distant and, therefore, more comfortable way than for women; but this is a hypothesis for future investigations. On the other hand, the differences found for the marital situation impose greater difficulty of interpretation. Why do people in stable unions respond more adequately to a questionnaire like MOSAI? The data collected in this study does not allow us to answer this question safely. However, it is possible that the variable "stable union" has measured other issues beyond what was intended, such as more or less conservatism, or more or less adherence to traditional and family values, for example. If this is the case, it seems reasonable to infer that these inclinations, measured indirectly, have influenced the quality of filling the questionnaire.

\section{CONCLUSION}

MOSAI has been validated and is suitable for use in other surveys with HCP in Brasil. 


\section{QUESTIONNAIRE (ENGLISH VERSION)}

\section{PLEASE READ THE STORY BELOW AND ANSWER QUESTIONS SUBSEQUENT}

\section{JUSSARA}

Jussara and her husband wanted a baby from the very beginning of their marriage, becausethey felt very lonely without a child. Then, they received the news that Jussara was pregnant with great joy. However, at 16 weeks, when the first ultrasound was performed, the doctor noticed that the fetus was anencephalic, that is, it had no brain. Upon hearing the diagnosis, Jussara's first thought was to let him to be born. However, she fears that keeping her pregnancy will cause even more suffering to her, her husband, and the fetus. Being in the second trimester of pregnancy, Jussara realizes that keeping or interrupting pregnancy will be a difficult decision.

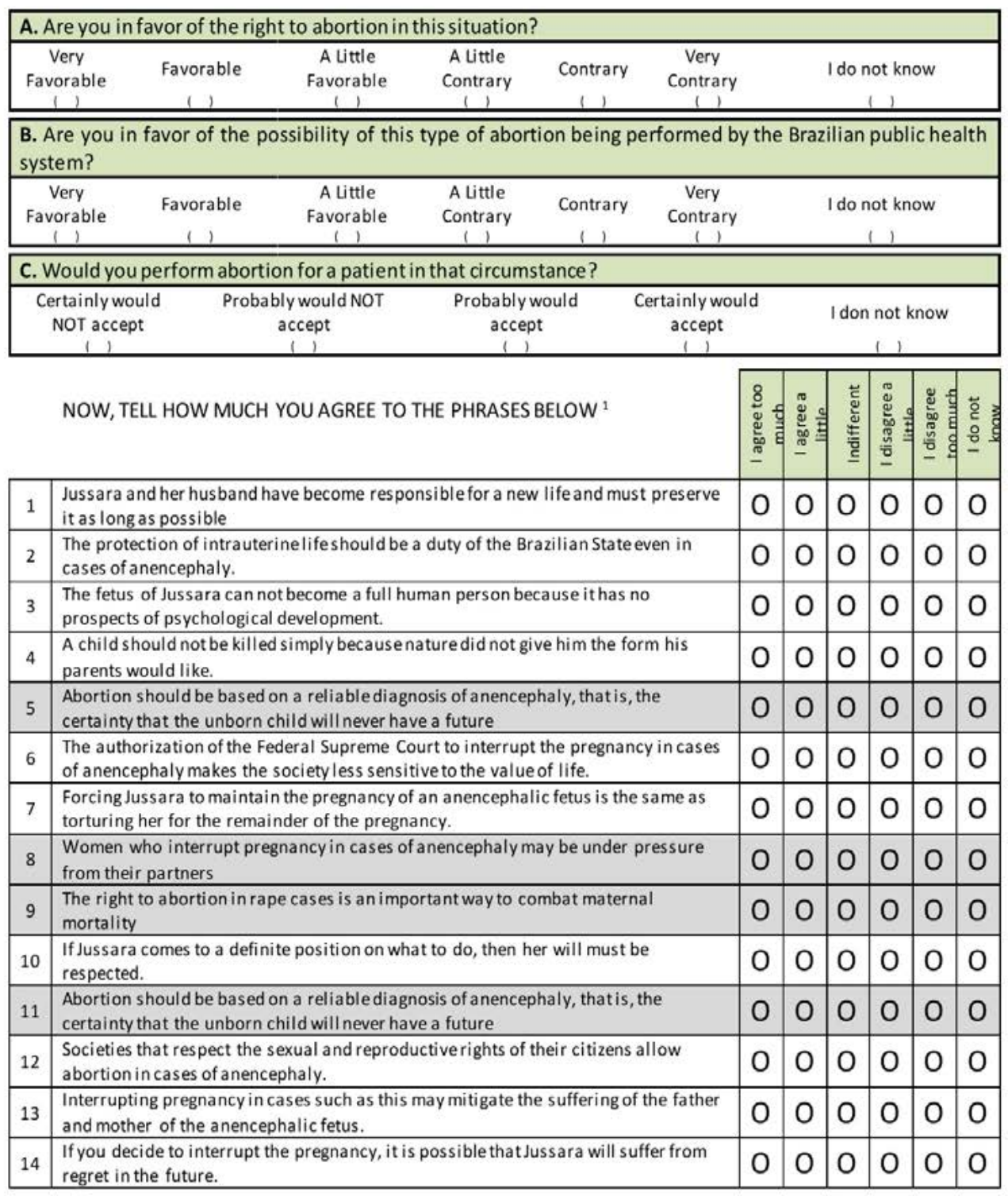

\footnotetext{
${ }^{1}$ Gray highlights were excluded from the final questionnaire model after confirmatory factorial analysis.
} 
PLEASE READ THE STORY BELOW ANDANSWER QUESTIONS SUBSEQUENT

GRAZIANE

Pregnant for 13 weeks, Graziane is a carrier of the rare Eisenmenger Syndrome. The problem has a high rate of maternal mortality. It leads the person to not be able to develop the simplest physical activities without feel ing a lack of air and fatigue. The only form of healing it is a heart transplant combined with a lung transplant. In case of pregnancy, the medical indication is the interruption. Even abortion involves risks for women, but lower than maintaining pregnancy, especially if performed during the first trimester. Anyway, Graziane and her husband want very much to have a child. And, for the moment, the fetus is in perfect formation.

\begin{tabular}{|c|c|c|c|c|c|c|}
\hline \multicolumn{7}{|c|}{ A. Are you in favor of the right to abortion in this situation? } \\
\hline $\begin{array}{c}\text { Very } \\
\text { Favorable } \\
(\end{array}$ & $\begin{array}{c}\text { Favorable } \\
(1,1)\end{array}$ & $\begin{array}{c}\text { A Little } \\
\text { Favorable } \\
(1,1\end{array}$ & $\begin{array}{c}\text { A Little } \\
\text { Contrary } \\
(, 1)\end{array}$ & $\begin{array}{c}\text { Contrary } \\
\text { ( ) }\end{array}$ & $\begin{array}{c}\text { Very } \\
\text { Contrary } \\
(1,1)\end{array}$ & I do not know \\
\hline
\end{tabular}

B. Are you in favor of the possibility of this type of abortion being performed by the Brazilian publichealth system?

\begin{tabular}{|c|c|c|c|c|c|c|}
\hline $\begin{array}{c}\text { Very } \\
\text { Favorable } \\
1 \quad 1\end{array}$ & $\begin{array}{c}\text { Favorable } \\
1, \\
\end{array}$ & $\begin{array}{c}\text { A Little } \\
\text { Favorable } \\
1 \quad 1\end{array}$ & $\begin{array}{c}\text { A Little } \\
\text { Contrary } \\
1 \quad 1\end{array}$ & $\begin{array}{c}\text { Contrary } \\
1, \\
\end{array}$ & $\begin{array}{c}\text { Very } \\
\text { Contrary } \\
1 \quad 1 \\
\end{array}$ & $\begin{array}{c}\text { I do not know } \\
(1,\end{array}$ \\
\hline \multicolumn{7}{|c|}{ C. Would you perform abortion for a patient in that circumstance? } \\
\hline \multicolumn{2}{|c|}{$\begin{array}{c}\text { Certainly would } \\
\text { NOT accept } \\
\end{array}$} & $\begin{array}{l}\text { would NOT } \\
\text { cept }\end{array}$ & \multicolumn{2}{|c|}{$\begin{array}{c}\text { Probably would } \\
\text { accept } \\
1 \quad 1\end{array}$} & $\begin{array}{l}\text { Certainly would } \\
\text { accept }\end{array}$ & Idon not know \\
\hline
\end{tabular}

\section{NOW, TELL HOW MUCH YOU AGREE TO THE PHRASES BELOW ${ }^{2}$} 15 The maintenance of such a risky pregnancy will be the same as signing the Graziane

16 The high mortality rates for pregnant women with this disease justify abortion to protect the mother's life

17 Indicating abortion in cases of Eisenmenger Syndrome is a cruel decision because it protects only one of the two people involved.

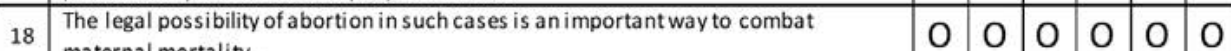

18 maternal mortality.

19 The laws that allow abortion in cases of Eisenmenger's Syndrome fail to protect the unborn child.

20 It is psychologically difficult for a health care professional to have to terminate the pregnancy of a healthy fetus

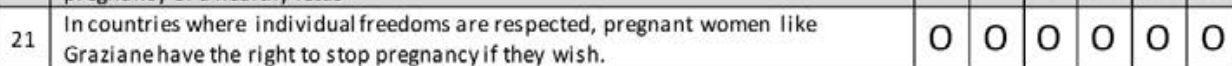

22 To accept abortion in such cases indicates that a banalization of the life of the unborn child has happen.

23 If Graziane decides to take the pregnancy forward, her attitude may be seen as a heroismby her family.

24 At 13 weeks' gestation, the Graziane fetus has a lower capacity to feel pain than a 24 born person.

25 Graziane must have complete freedom to choose to abort or maintain pregnancy, 25 because it is her lifeand her body that areat risk.

26 Being able to interrupt the pregnancy in case of risk of death for the pregnant woman is a fundamental right.

27 Performing abortion in cases like this affects a fetus that could have a normal future

27 ahead of it

28 Grazianeand her husband were aware of the risks when they freely decided to fulfill the dream of having a child.

${ }^{2}$ Gray highlights were excluded from the final questionnaire model after confirmatory factorial analysis. 


\section{MARINA}

Marina is 23 years old, evangelical and single. She was raped by a former partner at the aggressor's home. For fear, she did not seek immediate care and became pregnant because of rape. When she realized the pregnancy, she felt at risk, frightened and without alternatives. At that moment, she sought care in a basic health unit, where she was advised of the legal possibility of interrupting the pregnancy, as well as what would be ne cessary if she decided to perform it. However, Marina remained confused. More than once, she was told that she is responsible for the pregnancy, because she put herself in a situation of risk when visiting herformer partner. In addition, the induction of abortion contradicts their religious beliefs. Deeply distressed and without any support from friends or family, Marina does not know what to do.

\begin{tabular}{|c|c|c|c|c|c|c|}
\hline \multicolumn{7}{|c|}{ A. Are you in favor of the right to abortion in this situation? } \\
\hline $\begin{array}{c}\text { Very } \\
\text { Favorable } \\
(\end{array}$ & $\begin{array}{c}\text { Favorable } \\
\text {, }\end{array}$ & $\begin{array}{c}\text { A Little } \\
\text { Favorable } \\
\end{array}$ & $\begin{array}{l}\text { A Little } \\
\text { Contrary } \\
\text {, }\end{array}$ & $\begin{array}{c}\text { Contrary } \\
1,\end{array}$ & $\begin{array}{c}\text { Very } \\
\text { Contrary } \\
(1,1\end{array}$ & I do not know \\
\hline
\end{tabular}

B. Are you in favor of the possibility of this type of abortion being performed by the Brazilian public health system?

\begin{tabular}{|c|c|c|c|c|c|c|}
\hline $\begin{array}{c}\text { Very } \\
\text { Favorable } \\
1 \quad 1\end{array}$ & $\begin{array}{c}\text { Favorable } \\
1,1\end{array}$ & $\begin{array}{c}\text { A Little } \\
\text { Favorable } \\
1\end{array}$ & $\begin{array}{c}\text { A Little } \\
\text { Contrary }\end{array}$ & Contrary & $\begin{array}{c}\text { Very } \\
\text { Contrary } \\
1 \quad 1\end{array}$ & I do not know \\
\hline \multicolumn{7}{|c|}{ C. Would you perform abortion for a patient in that circumstance? } \\
\hline $\begin{array}{l}\text { Certainly would } \\
\text { NOT accept }\end{array}$ & & $\begin{array}{l}\text { would NOT } \\
\text { cept }\end{array}$ & $\begin{array}{r}\text { Probabl } \\
\text { acc }\end{array}$ & & $\begin{array}{l}\text { Certainly would } \\
\text { accept }\end{array}$ & I don not know \\
\hline
\end{tabular}

NOW, TELL HOW MUCH YOU AGREE TO THE PHRASES BELOW ${ }^{3}$

29 The right to abortion in rape cases is an important way to combat maternal

mortality

Marina is now suffering because of rape, but may suffer even more if she aborts and

feels guilty.

31 The right to abortion in cases of sexual violence contravenes the constitutional

principle of the defense of life.

32 The unborn child should not be killed just because Marina was unable to defend

herselffrom the ex-boyfriend's aggression.

33 In a secular State, the possibility of terminating pregnancy in cases of sexual

violence is guaranteed.

34 The right to termination of pregnancy in cases of sexual violence mitigates the

suffering of women.

35 Marina must keep in mind that life is sacred regardless of how it was generated

36 Legal abortion in cases of rape frees the victims of the horror of carrying a life

36 generated in an act of terrible violence

37 If performed in the first weeks of gestation, abortion will affect an embryo, which

does not yet have brain activity.

Discontinuation of a healthy fetus's pregnancy can be considered a form of violence

against the weakest

$0 \begin{array}{llllll}0 & 0 & 0 & 0 & 0 & 0\end{array}$

39

Marina's wish to have an abortion should be enough so that she could safely

interrupt the pregnancy.

40 If Marina is lying, then she has no right to an abortion because her sexual

40 relationship with the ex-boyfriend was voluntary.

41 In hos pitals, it is possible that many women lie to abort, trivializing the procedure.

41

42 The legal possibility of abortion in cases of rape res pects international agreements on sexual and reproductive human rights.

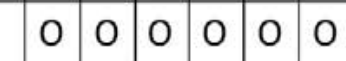

\begin{tabular}{llllllll}
0 & 0 & 0 & 0 & 0 & 0 \\
\hline
\end{tabular}

$\begin{array}{lllllll}0 & 0 & 0 & 0 & 0 & 0\end{array}$

$\begin{array}{lllllll}0 & 0 & 0 & 0 & 0 & 0\end{array}$

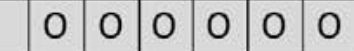
$\begin{array}{llllll}0 & 0 & 0 & 0 & 0 & 0\end{array}$

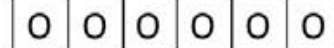

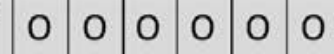
$\begin{array}{lllllll}0 & 0 & 0 & 0 & 0 & 0\end{array}$ $\begin{array}{lllllll}0 & 0 & 0 & 0 & 0 & 0\end{array}$

${ }^{3}$ Gray highlights were excluded from the final questionnaire model after confirmatory factorial analysis. 


\section{RESUMO}

RESUMO: No Brasil, o aborto induzido é permitido por lei em casos de estupro, risco de morte para a gestante e anencefalia fetal. Entretanto, a literatura relata que alguns médicos recusam atender mulheres com tais demandas, ou o fazem de maneira discriminatória.

OBJETIVO: Pré-testar, testar e avaliar as propriedades da medida do "Mosaico de opiniões sobre o aborto induzido", um questionário para investigar as perspectivas de profissionais da saúde brasileiros sobre a moralidade do aborto.

MÉTODOS: Primeiro, o questionário foi pré-testado em uma amostra intencional de especialistas. Em segundo lugar, foi testado em uma amostra aleatória de 32 profissionais da saúde. Finalmente, conduziu-se um estudo multicêntrico em sete hospitais universitários para avaliar as propriedades da medida do questionário.

RESULTADOS: Combinadas, as amostras das três fases totalizaram 430 sujeitos. No pré-teste e no teste, todos os aspectos avaliados obtiveram resultados satisfatórios. Na fase multicêntrica, a análise fatorial confirmatória levou a uma importante redução do questionário, que também obteve bons indicadores de confiabilidade, além da validade de construto e de critério.

CONCLUSÕES: O questionário foi validado e encontra-se apto para ser utilizado em outras pesquisas no Brasil.

PALAVRAS-CHAVE: Estudos de validação. Aborto induzido. Atitude do pessoal de saúde. Ética. Inquéritos e questionários.

\section{REFERENCES}

1. Diniz D, Dios VC, Mastrella M, Madeiro AP. A verdade do estupro nos serviços de aborto legal no Brasil. Rev Bioet. 2014;22(2):291-8.

2. Madeiro AP, Diniz D. Legal abortion services in Brazil: a national study Cien Saude Colet. 2016;21(2):563-72.

3. Menezes G, Aquino EML. Pesquisa sobre o aborto no Brasil: avanços e desafios para o campo da saúde coletiva. Cad Saúde Pública. 2009;25(supl.2):s193-s204

4. Silveira P, McCallum C, Menezes G. Personal experiences with induced abortions in private clinics in Northeast Brazil. Cad Saude Publica. 2016;32(2):e00004815

5. Cacique DB, Passini Junior $R$, Osis MIMD. Opiniões, conhecimento e atitudes de profissionais da saúde sobre o aborto induzido: uma revisão das pesquisas brasileiras publicadas entre 2001 e 2011. Saúde Soc. 2013;22(3):916-36

6. Faúndes $A$, Miranda L. "Ethics surrounding the provision of abortion care" Best Pract Res Clin Obstet Gynaecol. 2017;43:50-57.

7. Cacique DB, Passini Junior R, Osis MIMD. Validação de conteúdo do Mosaico de Opiniões sobre o Aborto Induzido (Mosai). Rev Assoc Med Bras. 2013;59(6):576-82

8. Shellenberg KM, Hessini L, Levandowski BA. Developing a scale to measure stigmatizing attitudes and beliefs about women who have abortions: results from Ghana and Zambia. Women Health. 2014;54(7):599-616.

9. Sorhaindo AM, Karver TS, Karver JG, Garcia SG. Constructing a validated scale to measure community-level abortion stigma in Mexico. Contraception. 2016;93(5):421-31.

10. Scholtes VA, Terwee CB, Poolman RW. What makes a measurement instrument valid and reliable? Injury. 2011;42(3):236-40.

11. Steinberg $\mid R$, Rubin LR. Psychological aspects of contraception, unintended pregnancy, and abortion. Policy Insights Behav Brain Sci. 2014;1(1):239-47.

12. Nomura RM, Benute GR, Azevedo GD, Dutra EM, Borsari CG, Rebouças MS, et al. Depression, emotional and social aspects in the abortion context: a comparison between two Brazilian capitals. Rev Assoc Med Bras. 2011;57(6):644-50

13. Hair JF, Black WC, Babin B|, Anderson RE, Tatham RL. Análise multivariada de dados. 6a. ed. Porto Alegre: Bookman; 2009.

14. Fornell $C$, Larcker DF. Evaluating structural equation models with unobservable variables and measurement error. J Mark Res. 1981;18(1):39-50.

15. Pagano M, Gauvreau K. Princípios de Bioestatística. São Paulo: Thomson; 2004

16. Galesic M, Bosnjak M. Effects of questionnaire length on participation and indicators of response quality in a web survey. Public Opin Q. 2009;73(2):349-60.
17. Terrível J, Rodrigues AT, Ferreira M, Neves C, Roque F, Silva OABC, et al. Conhecimento dos médicos relativo à prescrição de antibióticos e à resistência microbiana: estudo piloto de comparação de questionário online vs papel. R Epidemiol Control Infect. 2013;3(3):93-8.

18. Davidov E, Depner F. Testing for measurement equivalence of human values across online and paper-and-pencil surveys. Quality \& Quantity. 2011;45(2):375-90.

19. Prieto L, Alonso |, Lamarca R. Classical Test Theory versus Rasch analysis for quality of life questionnaire reduction. Health Qual Life Outcomes. 2003;1:27.

20. Grossi E, Groth N, Mosconi P, Cerutti R, Pace F, Compare A, et al. Development and validation of the short version of the Psychological General Well-Being Index (PGWB-S). Health Qual Life Outcomes. 2006:4:88.

21. Hair Jr JF, GTM Hult, Ringle CM, Sarstedt M. A primer on Partial Least Squares Structural Equation Modeling (PLS-SEM). Los Angeles: Sage Publications; 2014. 307p.

22. Godoy CLM. Vivências de mulheres que sofreram violência sexual e solicitaram interrupção legal de gestação [Tese de doutorado]. Campinas: Universidade Estadual de Campinas. Faculdade de Ciências Médicas; 2015.

23. Borges VTM, Magalhães CG, Martins AMVC, Matsubara BB. Síndrome de Eisenmenger na gravidez. Arq Bras Cardiol. 2008;90(5):e40-1.

24. Cartago RS, Alan PA, Benedicto J. Pregnancy outcomes in patients with severe pulmonary hypertension and Eisenmenger syndrome treated with sildenafil monotherapy. Obstet Med. 2014;7(1):40-2.

25. Callahan S. Pro-life feminism. In: Gensler HJ, Spurgin EWS, Swindal JC, eds. Ethics: contemporary readings. Routledge contemporary readings in philosophy. New York: Routledge - Taylor \& Francis Group; 2004.

26. Diniz D. Estado laico, objeção de consciência e políticas de saúde. Cad Saúde Pública. 2013;29(9):1704-6.

27. Ogland CP, Verona AP. Religion and attitudes toward abortion and abortion policy in Brazil. J Sci Study Relig. 2011;50(4):812-21.

28. Hoga LA, Rodolpho IR, Souza Penteado PE, Borges AL, Chávez Alvarez RE. Religiosity and sexuality: counseling provided by Brazilian Protestant pastors. Sex Reprod Healthc. 2013;4(2):57-63.

29. Palermo T, Infante Erazo M, Hurtado Pinochet V. Women's opinions on the legalisation of abortion in Chile 2009-2013. Cult Health Sex. 2015;17(7):873-90

30. Institute of Medicine (US), Committee for the Study of the Future of Public Health. The Future of Public Health. Washington: National Academies Press; 1988. 